Report Title:

CALDERON COKEMAKING

\title{
PROCESS/DEMONSTRATION PROJECT
}

Report Type: QUARTERLY

Reporting Period Start Date:05/26/2000 End Date: 08/25/2000

Principal Author(s): ALBERT CALDERON

Report Issue Date:

Submitting

Organization(s)

Name \& Address
09/19/2000

\section{CALDERON ENERGY COMPANY}

500 Lehman Avenue

P.O. Box 126

(1)

Bowling Green, OH 43402 


\section{DISCLAIMER}

This report was prepared as an account of work sponsored by an agency of the United States Government. Neither the United States Government nor any agency thereof, nor any of their employees, makes any warranty, express or implied, or assumes any legal liability or responsibility for the accuracy, completeness, or usefulness of any information, apparatus, product, or process disclosed, or represents that its use would not infringe privately owned rights. Reference herein to any specific commercial product, process, or service by trade name, trademark, manufacturer, or otherwise does not necessarily constitute or imply its endorsement, recommendation, or favoring by the United States Government or any agency thereof. The views and opinions of authors expressed herein do not necessarily state or reflect those of the United States Government or any agency thereof. 


\section{QUARTERLY TECHNICAL PROGRESS REPORT \\ CALDERON COKEMAKING PROCESS/DEMONSTRATION PROJECT \\ CALDERON ENERGY COMPANY \\ COOPERATIVE AGREEMENT NO. DE-FC22-95PC92638}

Reporting Period: 5-26-00 to 8-25-00

Date of Report: 9-19-00; Award Date: 5-25-95; Anticipated Completion Date: 11-25-00

Total Project: $\$ 6,332,060.00 \quad$ Total DOE Share: $\$ 3,039,389.00$

Contracting Officer's Representative (COR): Carl Maronde;

Project Director: Albert Calderon

\section{Abstract}

This project deals with the demonstration of a coking process using proprietary technology of Calderon, with the following objectives geared to facilitate commercialization:

(i) making coke of such quality as to be suitable for use in hard-driving, large blast furnaces;

(ii) providing proof that such process is continuous and environmentally closed to prevent emissions;

(iii) demonstrating that high-coking-pressure (non-traditional) coal blends which cannot be safely charged into conventional by-product coke ovens can be used in the Calderon process;

(iv) conducting a blast furnace test to demonstrate the compatibility of the coke produced;

(v) demonstrating that coke can be produced economically, at a level competitive with coke imports; and

(vi) applying the Calderon technology to making additional iron units. 
The activities of the past quarter were focused on the following:

- Bethlehem Steel's withdrawal and efforts expended to substitute U.S. Steel for Bethlehem.

- Assessment work performed with U.S. Steel to show that the Calderon Technology has merit and would add to U.S. Steel's economic benefit by being involved in it, including for making additional iron units.

- Addressing material selection and heat input capacity to increase heat input into the processing reactor by actual modelling of such approach.

- Construction of two full size courses of heating tiles to verify the manufacturing and the fitting of the tiles with one another.

- Making available equipment to test carbon deposition on sorbent.

- Permitting issues. 


\section{TABLE OF CONTENTS}

Introduction

Accomplishments and Discussion

Conclusion
Page 1

Page 1

Page 6 


\section{Introduction}

The commercialization path of the Calderon cokemaking process consists of the following general phases:

Phase I-- Proof of capability to produce acceptable product coke, proof of the process being environmentally closed, proof that non-conventional coal blends can be used, and proof that coke can potentially be economically produced domestically using U.S. metallurgical coals at a level competitive with low cost coke imported from foreign countries that are not subjected to U.S. environmental standards.

Phase II-- Scale-up of coking reactor to full size Commercial Demonstration Unit (CDU) in support of first commercial facility.

Phase III-- Construction and operation of first commercial facility.

Phase IV-- Making use of the Calderon technology for its application to make additional iron units.

Phase V-- Aggressive worldwide commercialization of the Calderon technology to attain a sizeable market share by producing a premium product at a competitive price.

Accomplishments and Discussion

Bethlehem Steel's Withdrawal and Efforts Expended to Substitute U.S. Steel for Bethlehem

As reported in the several previous reports, the members of the team for this project were Bethlehem Steel representing the steel industry, Bechtel representing the constructor 
and Calderon representing the prime mover of the project and the provider of the technology.

On July 17, 2000, Bethlehem Steel wrote a letter of withdrawal from the project to Congressman Regula, Chairman of the House Appropriations Subcommittee for Interior and Related Agencies (see letter attached). The reason for such withdrawal was commercial and did not signify a change in Bethlehem's assessment of the Calderon Cokemaking Process. Bethlehem stated in its letter that it continued to believe that the Calderon Process could provide a much needed method of producing low cost and high quality blast furnace coke; further, the letter encouraged the Subcommittee and the Department of Energy to continue their support of this project as it undergoes restructuring and the sourcing of other private sector funds.

Since having a steel company involved in the project is of great importance, Calderon without delay opened a dialogue with U.S. Steel with the intention of having Bethlehem replaced by U.S. Steel; Calderon apprised NETL of this development. U.S. Steel has excess cokemaking capacity in Clairton, PA, and is selling coke to others. However, in view of U.S. Steel's 1997 support of the successful work done at Alliance to make high quality coke, U.S. Steel agreed to consider the application of the Calderon Process to make coal based directly reduced iron (DRI) in the same reactor as that used for coke. U.S. Steel Research felt that the Calderon technology may produce DRI more efficiently than the DRI produced in a Rotary Hearth furnace which is coal based.

\section{Assessment Work Performed with U.S. Steel}

U.S. Steel Research decided that before recommending the teaming with Calderon to upper management that an assessment be made in-house to ascertain whether or not the 
Calderon Process has the potential of being economically competitive. Such an assessment was made to produce DRI commercially at a large enough capacity that will make 1.2 million tons of hot metal/year. The assessment concluded that the Calderon Process will have a capital cost of $\$ 90$ million against a capital cost of $\$ 195$ million for the Rotary Hearth. With respect to operating cost, the Calderon Process will produce DRI for $\$ 63.24 /$ ton against $\$ 80.70 /$ ton with a credit of $\$ 10$ for steam for the Rotary Hearth (see report attached). The Calderon process may also have a steam credit, but this issue was not covered in the economic assessment.

U.S. Steel Research decided to recommend to its Vice President of Technology, to support the Calderon Technology to the extent of refurbishing Calderon's pilot facility in Alliance, Ohio, and conduct a series of tests on condition that certain issues relating to material selection and heat input capacity be addressed. A letter from U.S. Steel would be forthcoming after Labor Day. Once such tests are determined to be successful the next step would be to proceed with the construction and operation of a full size commercial reactor.

\section{Addressing Material Selection and Heat Input Capacity to Increase Heat Input into Reactor}

The material selection will be addressed by a study made by a German company which has extensive expertise in heating coal. The heat input into the reactor has been initiated by building a model to study the behavior of material at the discharge end of the reactor to increase heat input to the reactor. (See photograph 1 attached). 


\section{Construction of Two Full Size Courses of Tiles to Verify Manufacture and Fit}

Another area where progress was made during the quarter is in the manufacture of the $\mathrm{SiC}$ tiles; two courses were completed (see photograph 2 attached). The third course which consists of the plenum tiles will be completed during the next quarter. A problem was discovered in flue mating with the transition tiles. Changes are being made to the molds to overcome the problem.

\section{Making Available Equipment to Test Carbon Deposition on Sorbent}

With respect to the deposition of carbon on the sorbent in the hot gas cleanup, in the event that the hydrocarbons in the volatile matter are pre-cracked within the reactor and the raw gas not having a sufficiency of hydrocarbons for carbon deposition, the following arrangement is now in place which consists of a diesel engine, a bed of sorbent, a drum with diesel fuel and ancillary equipment including a burner to heat the sorbent. The plan is to inject excess diesel fuel (hydrocarbon) into the flue gas from the diesel engine and such flue gas will be fed through the hot sorbent to demonstrate that carbon can be deposited on the sorbent (see photograph 3 of arrangement). Testing will commence after completion of instrumentation and test plan.

\section{Permitting Issues}

The permit for the installation of the full size reactor at LTV was not received during the quarter. There are still some minor issues raised by the City of Cleveland's Environmental Division, the local permitting authority which serves as a contractor to Ohio EPA, surrounding the storage and handling of limestone and related particulate emissions control measures. The information most recently requested by the City of Cleveland includes 
the size of the limestone sorbent to be used; whether the limestone is in pebble or powder form; moisture maintenance in the limestone to avoid dust; water addition; limestone handling control measures; and how control-scooping and control-dumping of limestone is achieved, and does each function need an emission control measure. These issues will be taken up with the City of Cleveland, Department of Public Health, as agent for Ohio EPA.

At the request of LTV Steel, Calderon applied for on June 8, 2000, and received on July 27, 2000, a guidance letter from U.S.EPA Region 5 (see attached), confirming U.S.EPA's concurrence that the full-size reactor is a separate source of air emissions from LTV Steel's Cleveland Works. U.S.EPA Region 5 also expressed that it looked forward to working with the Ohio Environmental Protection Agency to ensure that Calderon receives any necessary permits and that it anticipated environmentally beneficial results from Calderon's process. Calderon understands that the project and letters received reviews within both Region 5 and the Office of Air and Radiation, in Washington, D.C., prior to the agency's release of its July 27, 2000 guidance letter. 


\section{Conclusion}

During the coming quarter, it is planned to continue working with U.S. Steel with the goal of U.S. Steel becoming part of the team for the project. Once U.S. Steel joins the team, a revised Statement of Work will be prepared and presented to NETL for approval and work will begin consistent with the revised Statement of Work. Issues regarding the issuance of a Permit will continue to be addressed.

Submitted by:

\section{Albert Calderon \\ Project Director}




\section{Bethlehem Steel Corporation}

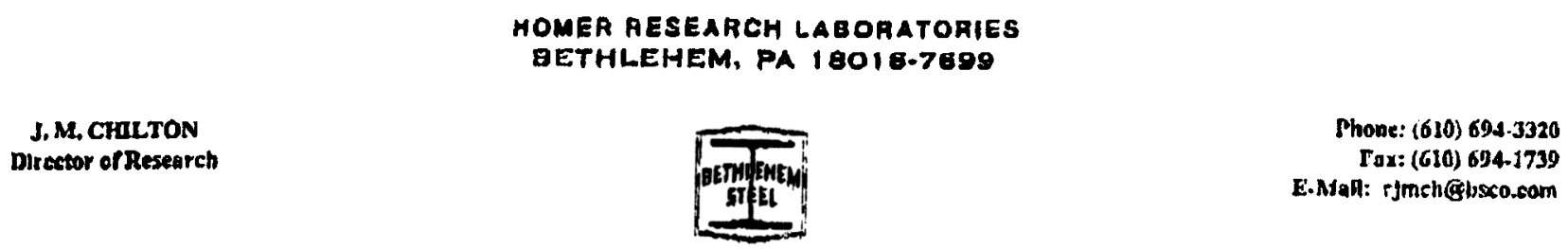

July 17,2000

Ref: $100-2411$

Honorable Ralph Regula

Member of Congress

Chairman, House Appropriations Subcommittee

For Interior and Related Agencies

Washington, DC

Dear Congressman Regula:

We wish to advise you that Bethlehem Steel has decided to withdraw from making an investment in Calderon Coke and the demonstration of the Calderon Process for Metallurgical Cokemaking. We reached this decision very reluctantly and after several months of negotiations concerning commercial joint venture terms with the other proposed members of the venture, Bechtel Corporation and Calderon Energy.

We want you and your subcommittee to know that our withdrawal does not signify a change in our technical assessment of the Calderon Cokemaking Process. We continue to believe that the Calderon Process could provide a much needed method of producing a low cost and high quality blast furnace coke.

We encourage the Subcommittee and the Department of Energy to continue their support of this project as it undergoes restucturing and the sourcing of other private sector funds.

Sincerely,
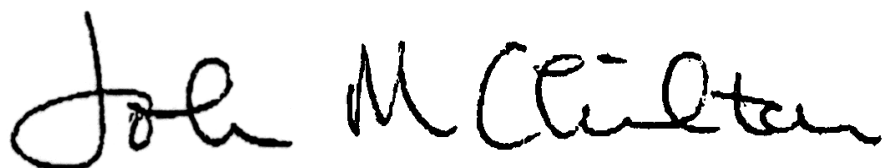

John M. Chilton

bcc: MJRoberts

RWBouman

JLLazar 


\section{Calderon Ironmaking Project *}

\section{Technology}

- Proposed Concept has Foundation in Recently Tested Cokemaking Technology

- USS Tests on Demonstration Unit at Alliance

- DOE Funding for Commercial Demonstration Approved

\section{Technical Issues}

- Heat Transfer Mechanism

- Operating Problems: Flow of materials, pushing operation

- Degree of Metallization

- Specific Productivity

- Product Physical Characteristics: Size, Strength, Density

- Hot Transport to Melting Unit

- Other : Materials of Construction, Ability to use reverts as feed, Collection of $\mathrm{Zn}$ and lead in off-gas

\section{Cost Competitiveness with RHF Process}

- Lower Capital Costs

- No Agglomeration Equipment Required

- Tube Reactor vs. RHF

- Lower Operating Cost

- No agglomeration of feed

- Coal is the main fuel compared to natural gas for RHF

- No possibility of reoxidation because the atmosphere in the reactor is reducing

- Higher productivity compared to RHF?

- Less manpower for operation?

\section{First Phase Test Objectives}

- Prove feasibility of the process (Does it work and to what degree?)

- Operating Problems: Flow of materials, pushing operation

- Operating Characteristics: Temperature, Pressure, Time, Gas Flow Rate, Composition

- Product Characteristics: Degree of Metallization, Chemistry (Gangue, Zn, S, etc.) Size, Strength

\section{Second Phase Test Objectives}

- Sensitivity to Various Feed and Reductant Materials (Chemistry, Size, Mineralogy, etc.), Productivity Issues

- Product Characteristics: Metallization, Chemistry, Size, Strength

- Various Concentrates: Minntac, IOC

- Reverts: Blast Furnace and Steelmaking dusts and sludges

- Various Reductants: Coals of different VM

- Miscellaneous: Tires, Plastics

- Process Optimization

* This report was prepared by U.S. Steel Research 


\begin{tabular}{|c|c|c|}
\hline \multicolumn{3}{|l|}{ Design Basis } \\
\hline $\begin{array}{l}\text { Feed and } \\
\text { Reductant }\end{array}$ & \multicolumn{2}{|c|}{$\begin{array}{l}\text { All purchased ore and coal } \\
\text { Ore @ } 63 \% \text { Fe, Coal }<30 \% \text { VM } \\
750 \text { TPD Ore and } 250 \text { TPD Coal per Reactor }\end{array}$} \\
\hline DRI Product & \multicolumn{2}{|c|}{$\begin{array}{l}750 \text { TPD Ore and } 250 \text { TPD Coal per Keactor } \\
700 \text { TPD per Reactor } \\
\text { Fe }(t) 67.5 \%, 90 \% \text { Metallization }\end{array}$} \\
\hline Hot Metal & \multicolumn{2}{|l|}{$\frac{\mathrm{Fe}(\mathrm{t}) 67.5 \%, 90 \% \mathrm{Met}}{500 \mathrm{TPD} \text { per Reactor }}$} \\
\hline Design Capacity & \multicolumn{2}{|l|}{ 1.2 MM TPY Hot Metal } \\
\hline Hours/Year & \multicolumn{2}{|c|}{7885 (90\% Availability) } \\
\hline $\begin{array}{l}\text { Number of } \\
\text { Reactors } \\
\text { Required } \\
\end{array}$ & \multicolumn{2}{|c|}{$\begin{array}{l}7885 \text { (90\% Availability) } \\
\text { Annual Production per Reactor: } 164,250 \text { TPY } \\
\text { Reactors Required : } 7.3 \\
\text { (Assume 8) }\end{array}$} \\
\hline $\begin{array}{l}\text { Capital Cost } \\
\text { Estimate }\end{array}$ & \multicolumn{2}{|c|}{$\begin{array}{l}\text { (Assume 8) } \\
\text { Per Correspondence from Al Calderon } \\
\text { ** Cost of } 4 \text { Reactors: } \$ 18.65 \\
\text { (Assumes } 15 \% \text { discount for multiple reactors) } \\
\text { **Cost of Gas Handling Equipment for } 4 \text { Reactors: } \$ 4.6 \mathrm{MM} \\
\text { (Assumes one gas handling unit per two reactors, cost increase of only } 20 \% \\
\text { assumed from single reactor gas cleaning system) }\end{array}$} \\
\hline \multicolumn{2}{|l|}{8 Reactors } & $\$ 37.3 \mathrm{MM}$ \\
\hline \multicolumn{2}{|c|}{8 Reactors } & \$ $9.2 \mathrm{MM}$ \\
\hline \multicolumn{2}{|c|}{$\begin{array}{l}\text { Hot Gas Treatment } \\
\text { Miscellaneous Costs (Piping, Electrical, Construction, } \\
\text { Instrumentation, Civil Work, etc.) }\end{array}$} & \$ $24.7 \mathrm{MM}$ \\
\hline \multicolumn{2}{|c|}{$\begin{array}{l}\text { Instrumentation, Civil Work, et.) } \\
\text { Ancillary Equipment (Cranes, Lining Towers, Utilities, } \\
\text { Spares, etc.) }\end{array}$} & $\$ 4.6 \mathrm{MM}$ \\
\hline \multicolumn{2}{|c|}{$\begin{array}{l}\text { Spares, etc.) } \\
\text { Engineering, Procurement, Construction Services @ 4\% }\end{array}$} & $\$ 2.3 \mathrm{MM}$ \\
\hline \multicolumn{2}{|c|}{ Contingency@10\% } & \$ $7.8 \mathrm{MM}$ \\
\hline \multicolumn{2}{|c|}{ Royalty Fees@5\% } & $\$ 4.3 \mathrm{MM}$ \\
\hline \multicolumn{2}{|c|}{ Total Estimated Capital } & \$ $90.2 \mathrm{MM}$ \\
\hline
\end{tabular}

Notes

... Cost estimates scaled-up from the single demonstration reactor.

... The above costs include reactor and gas handling only.

... Heated area per reactor: 1991 sq. feet, for 8 reactors : 15,928 sq. feet 
Capital Costs: RHF vs. Calderon Ironmaking

\begin{tabular}{|c|c|c|}
\hline \multicolumn{3}{|c|}{ RHF Process } \\
\hline \multicolumn{3}{|l|}{ Design Basis } \\
\hline Feed & \multicolumn{2}{|c|}{ QCM Concentrate and coal with 75\% Fixed Carbon } \\
\hline DRI Product & \multicolumn{2}{|c|}{ 1.5 MM NTPY (Estimated 1.25 Tons DR/Ton Hot Metal) } \\
\hline Hot Metal & \multicolumn{2}{|c|}{$1.2 \mathrm{MM}$ NTPY } \\
\hline Hours/Year & \multicolumn{2}{|c|}{ Cocidance Time. $15-20$} \\
\hline $\begin{array}{l}\text { Rotary Hearth } \\
\text { Furnaces }\end{array}$ & \multicolumn{2}{|c|}{$\begin{array}{l}2 \text { Furnaces, } 2000 \text { to } 2400 \mathrm{~F} \text { Operating Temperature, Residence Time: } 15-20 \\
\text { minutes, Offgas Temp.: } 2000 \mathrm{~F}\end{array}$} \\
\hline \begin{tabular}{l|} 
Capital Cost \\
Estimate
\end{tabular} & \multicolumn{2}{|c|}{$\begin{array}{l}\text { Estimated from Published Work and Private Communications } \\
\text { Applicable to Brown Field Site with Use of Some Existing Facilities }\end{array}$} \\
\hline \multicolumn{2}{|c|}{ RHF Area Equipment, Freight, and Construction } & $\$ 105.2 \mathrm{MM}$ \\
\hline \multicolumn{2}{|c|}{ Cold Briquetting Equipment, Freight, and Construction } & \$ $39.6 \mathrm{MM}$ \\
\hline \multicolumn{2}{|c|}{ Gas Handling } & $\$ 10.0 \mathrm{MM}$ \\
\hline \multicolumn{2}{|c|}{ Raw Materials Handling Equipment and Construction } & $\$ 12.0 \mathrm{MM}$ \\
\hline \multicolumn{2}{|c|}{ Field Services, Construction, Management } & $\$ 28.4 \mathrm{MM}$ \\
\hline \multicolumn{2}{|c|}{ Total Estimated Capital } & \$ $195.2 \mathrm{MM}$ \\
\hline \multicolumn{3}{|c|}{ Calderon Process } \\
\hline \multicolumn{3}{|l|}{ Design Basis } \\
\hline Feed & \multicolumn{2}{|c|}{$\begin{array}{l}\text { QCM Concentrate and Coal with }<30 \% \text { VM } \\
750 \text { TPD Ore and } 250 \text { TPD Coal per Reactor }\end{array}$} \\
\hline DRI Product & \multicolumn{2}{|c|}{$\begin{array}{l}700 \text { TPD per Reactor } \\
\mathrm{Fe}(\mathrm{t}) 67.5 \%, 90 \% \text { Metallization }\end{array}$} \\
\hline Design Capacity & \multicolumn{2}{|c|}{ 1.2 MM TPY Hot Metal, 500 TPD per Reactor } \\
\hline Hours/Year & \multicolumn{2}{|c|}{7885 ( $90 \%$ Availability) } \\
\hline $\begin{array}{l}\text { Reactors } \\
\text { Required }\end{array}$ & \multicolumn{2}{|c|}{$\begin{array}{l}\text { Annual Production per Reactor: 164,250 TPY } \\
\text { Reactors Required : } 7.3 \text { (Assume 8) }\end{array}$} \\
\hline $\begin{array}{l}\text { Capital Cost } \\
\text { Estimate } \\
\text { (Reactor and } \\
\text { Gas Handling } \\
\text { Only) }\end{array}$ & \multicolumn{2}{|c|}{$\begin{array}{l}\text { Per Correspondence from Al Calderon } \\
* * \text { Cost of } 4 \text { Reactors: } \$ 18.65 \text { (Scaled-up from the demonstration unit. } \\
\text { Assumed } 15 \% \text { discount for multiple reactors) } \\
\text { **Cost of Gas Handling Equipment for } 4 \text { Reactors: } \$ 4.6 \mathrm{MM} \\
\text { (Assumes one gas handling unit per two reactors, cost increase of only } 20 \% \\
\text { assumed from single reactor gas cleaning system) }\end{array}$} \\
\hline \multicolumn{2}{|l|}{8 Reactors } & \$37.3 MM \\
\hline \multicolumn{2}{|c|}{ Hot Gas Treatment } & $\$ 9.2 \mathrm{MM}$ \\
\hline \multicolumn{2}{|c|}{$\begin{array}{l}\text { Miscellaneous Costs (Piping, Electrical, Construction, } \\
\text { Instrumentation, Civil Work, etc.) }\end{array}$} & \$ $24.7 \mathrm{MM}$ \\
\hline \multicolumn{2}{|c|}{$\begin{array}{l}\text { Ancillary Equipment (Cranes, Lining Towers, Utilities, } \\
\text { Spares, etc.) }\end{array}$} & $\$ 4.6 \mathrm{MM}$ \\
\hline \multicolumn{2}{|c|}{ Engineering, Procurement, Construction Services@4\% } & $\$ 2.3 \mathrm{MM}$ \\
\hline \multicolumn{2}{|c|}{ Contingency@10\% } & \$ $7.8 \mathrm{MM}$ \\
\hline \multicolumn{2}{|c|}{ Royalty Fees@5\% } & $\$ 4.3 \mathrm{MM}$ \\
\hline \multicolumn{2}{|c|}{ Total Estimated Capital } & \$90.2 MM \\
\hline
\end{tabular}


Operating Cost Comparison: Calderon vs. RHF

\begin{tabular}{|l|l|l|l|l|}
\hline $\begin{array}{l}\text { Operating Cost } \\
\text { Estimate }\end{array}$ & $\begin{array}{l}\text { Unit/Unit } \\
\text { DRI }\end{array}$ & Cost/Unit & $\begin{array}{l}\text { Cost/Ton } \\
\text { DRI }\end{array}$ & Total \\
\hline Calderon Process & & & & \\
\hline Raw Materials & & & & \\
\hline Ore Concentrate, Ton & 1.50 & $\$ 25.90$ & $\$ 38.85$ & \\
\hline Coal, Ton & 0.50 & $\$ 40$ & $\$ 20.00$ & \\
\hline Total RM Cost & & & & $\$ 58.85$ \\
\hline Conversion Cost & & & & $\$ 10.24$ \\
\hline Total Cost & & & & $\$ 63.24$ \\
\hline & & & & \\
\hline RHF Based Process & & & & \\
\hline Raw Materials & & & & \\
\hline Ore Concentrate, Ton & 1.33 & $\$ 25.90$ & $\$ 34.45$ & \\
\hline Coal, Ton & 0.38 & $\$ 48.18$ & $\$ 18.30$ & \\
\hline Binder, $\$$ & & & $\$ 4.00$ & \\
\hline Total RM Cost & & & & $\$ 56.75$ \\
\hline Natural Gas, MMBtu & 2.5 & $\$ 3.0$ & $\$ 7.50$ & \\
\hline Electricity, kWh & 80 & 0.035 & $\$ 2.80$ & \\
\hline Total Utilities & & & & $\$ 10.30$ \\
\hline Maintenance \& Spares & & & & $\$ 3.85$ \\
\hline Labor & & & & $\$ 6.80$ \\
\hline GS\&A & & & & $\$ 3.00$ \\
\hline Total & & & & $\$ 80.70$ \\
\hline
\end{tabular}

... Conversion cost details of Calderon not available

... Consumption and cost data mostly from Direct Reduced Iron (Feinman and Mac Rae)

... Maintenance and Spares estimate 3\% of \$/installed annual ton

... Labor 0.2-0.4 mh/mt @ \$25/mh

... Overhead costs (GS\&A) $\$ 3-5 / \mathrm{mt}$

... Steam credits not included in RHF analysis. Estimated at $\$ 10 /$ ton in Chicago area. 


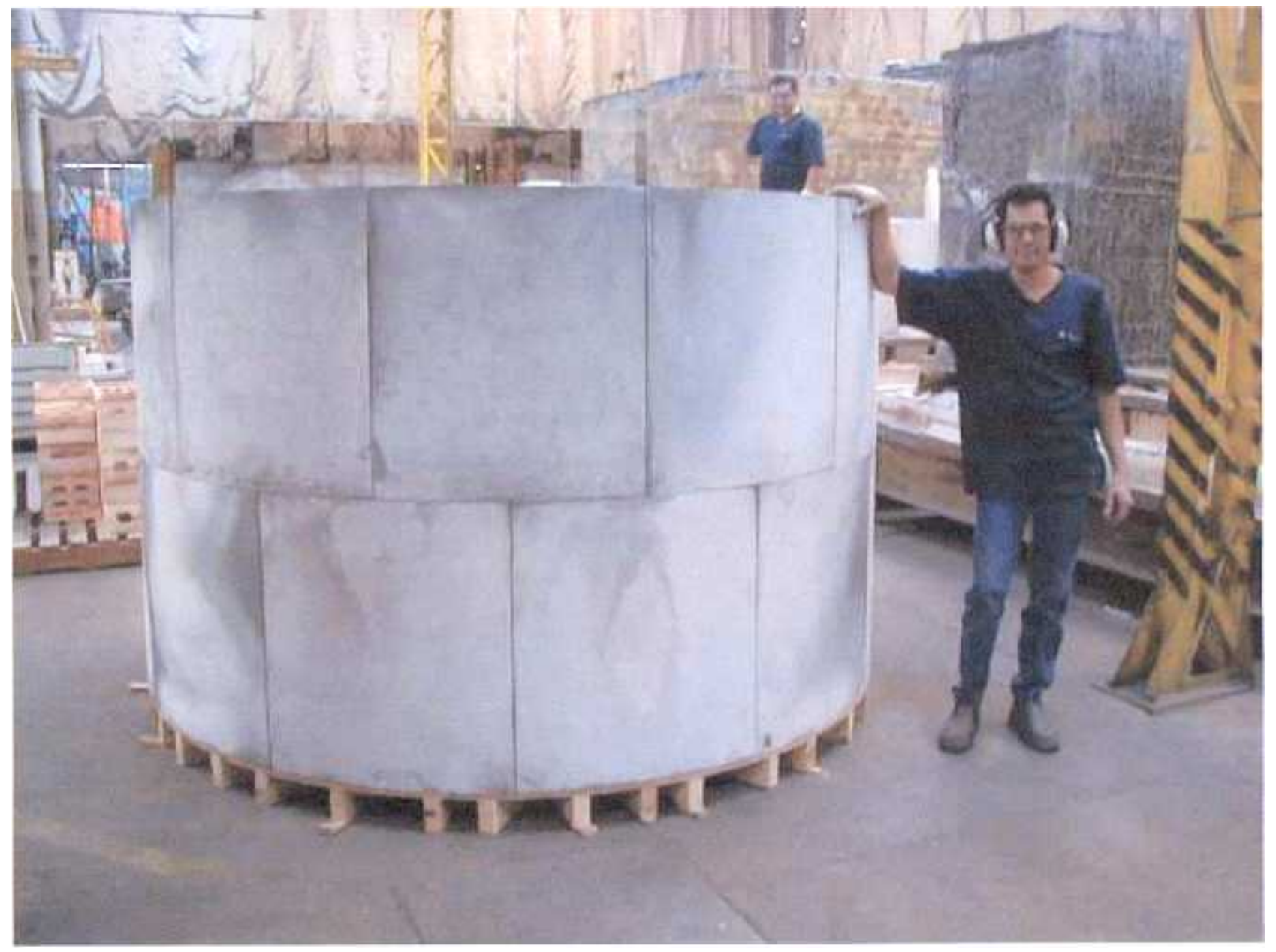

Photograph 2 


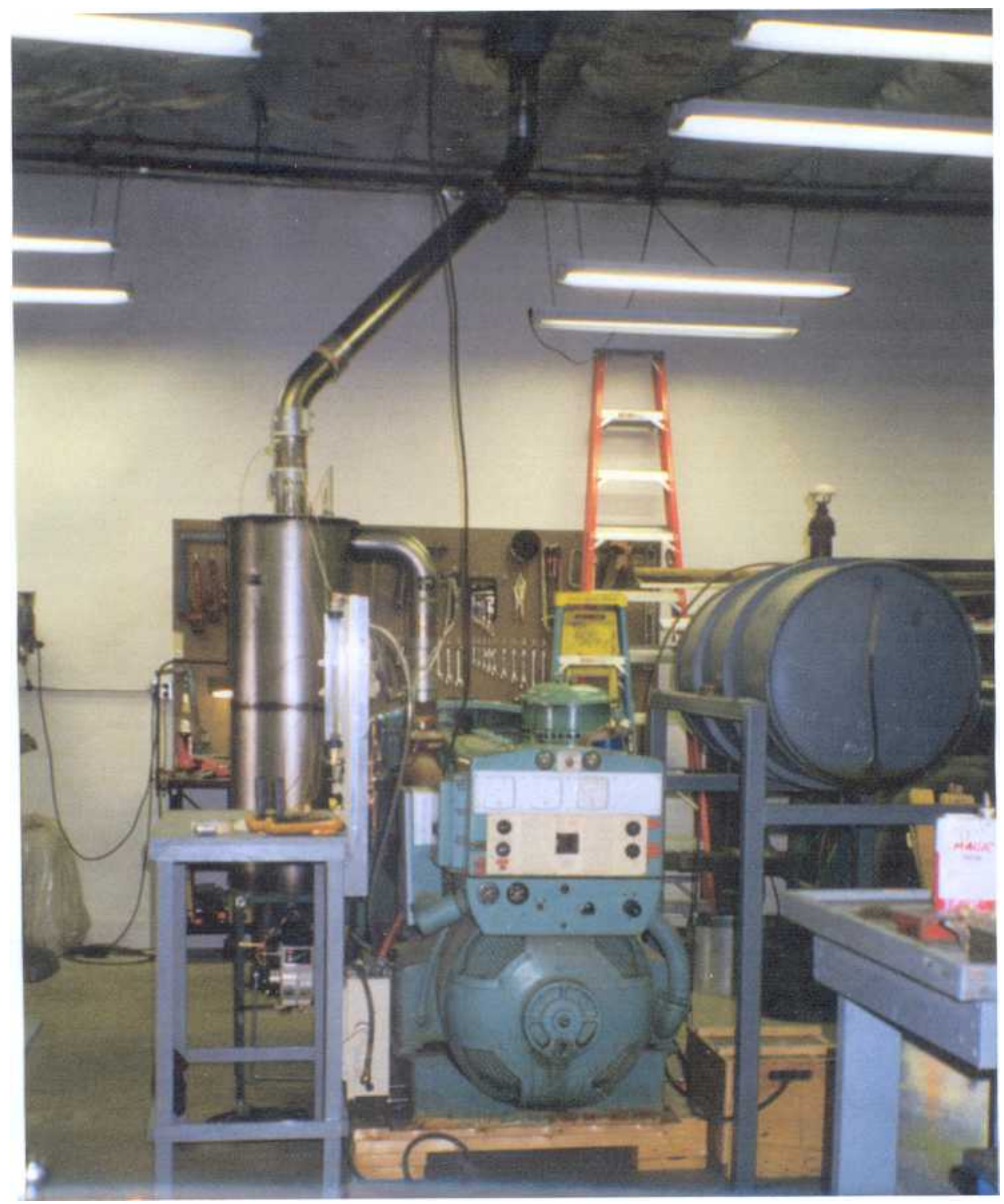

Photograph 3 


\title{
UNITED STATES ENVIRONMENTAL PROTECTION AGENCY \\ REGION 5 \\ 77 WEST JACKSON BOULEVARD \\ CHICAGO, IL 60604-3590
}

\section{JuL \& 2000}

REPLY TO THE ATTENTION OF:

\author{
$(A R-18 J)$
}

\author{
Albert Calderon, President \\ Calderon Energy Company of Bowling Green \\ P.O. Box 126 \\ Bowling Green, Ohio 43402
}

Dear Mr. Calderon:

We have received your letter and enclosure dated June 8, 2000, regarding your request for a separate source determination for your proposed research and development facility, Calderon Coke LLC (Calderon). You propose to construct and operate Calderon on property leased from LTV Steel (LTV). Calderon, which will be researching and developing a novel cokemaking process, shares the same Standard Industrial Classification (SIC) code with LTV.

40 C.F.R. \$ 52.21(b) (5) and (6) defines a stationary source as "all of the pollutant emitting activities which belong to the same industrial grouping, are located on one or more contiguous or adjacent properties, and are under the control of the same person (or persons under common control)...." Pollutant-emitting activities are part of the same industrial grouping if the first two digits of their SIC codes are the same. 40 C.F.R.\$ $52.21(b)(6)$.

From our review of your June 8, 2000, correspondence, it appears that there is no evidence of common control between calderon and LTV. As noted above, common control is necessary to a finding that adjacent facilities with the same SIC code constitute a single source. Therefore, it does not appear, based on the information presented, that Calderon and LTV are a single source for purposes of applicability of new source review requirements. However, because we have only limited information, this document constitutes guidance rather than a formal applicability determination.

We look forward to working with the Ohio Environmental Protection Agency to ensure that Calderon receives any necessary permits and anticipate environmentally beneficial results from Calderon's 
novel cokemaking process. If we can answer any questions regarding this matter, please contact Steve Gorge, of my staff, at (312) 353-4145.

Sincerely yours,

$$
\text { Pamela Blackleg }
$$

Pamela Blakley, Chief

Permits and Grants Section (IL/IN/OH)

CC: Mike Hopkins, OEPA 